\title{
Film, Literature, and Education: Trace of Ecopsychology Research in Indonesia
}

\author{
Anas Ahmadi $^{1 *}$, Abd. Syukur Ghazali², Taufik Dermawan ${ }^{3}$, Maryaeni ${ }^{2}$ \\ ${ }^{1}$ Department of Indonesian Language and Literature, State University of Surabaya, Lidah Wetan, East Java, Indonesia \\ ${ }^{2}$ Department of Indonesian Literature, State University of Malang, 5 Semarang Street, East Java, Indonesia \\ ${ }^{3}$ Department of Indonesian Literature, State University of Malang (Universitas Negeri Malang), 5 Semarang Street, East Java, Indonesia
}

Corresponding Author: Anas Ahmadi, E-mail: anasahmadi@unesa.ac.id

\section{ARTICLE INFO}

Article history

Received: June 19, 2017

Accepted: August 21, 2017

Published: August 31, 2017

Volume: 8 Issue: 4

Advance access: August 2017

Conflicts of interest: None

Funding: None

\section{Key words:}

Ecopsychology,

Film,

Literature,

Education

\begin{abstract}
In this study, it is explained about the development of ecopsychology in Indonesia. Related to that, the research focus are ecopsychology development and ecopsychology concretization of education in Indonesia. This research uses descriptive-qualitative approach to explain about ecopsychology in Indonesia. Based on the research results, the findings are as follows. First, the ecopsychology development in Indonesia has existed and characterized by the research which is related to ecopsychology. The research about ecopsychology in Indonesia is more likely in literature, film, and media. Ecopsychology study in psychology or ecology fields do not exist in Indonesia. Second, the ecopsychology concretization of education in Indonesia appears in the study of Literary Psychology. In the study of Literary Psychology, ecopsychology is given to students with stages (1) first stage: initial understanding of ecopsychology; (2) second stage: understanding of field in ecopsychology; (3) third stage: understanding of literature in ecopsychology perspective and (4) fourth stage: ecopsychology application in literary study.
\end{abstract}

\section{INTRODUCTION}

\section{History of Ecopsychology Development}

The issue of ecopsychology study begins to be popularly discussed in 1990s. This is marked by the appearance of Roszak writing, et.al. (1995) that starts on ecopsychology and its study types. In its further developments, there are writings that reinforce and sharpen ecopsychology study. Nevertheless, it is undeniable that there are other similar fields that intersect/close to ecopsychology as follows.

First, ecolinguistics (Stibbe, 2015, Schultz, 2001) that explains about language and environment. This study is actually not separated from the thought of its predecessor, namely Sapir (1912: 227) describes that the environment fact is reflected through the language. Conversely, language can also be reflected through the environment. Sapir's view is a prototype of relational reflection between language and environment for the successors in the present.

Second, ecocriticism (Glotfelty \& Fromm, 1996; Garrad 2004; Clark, 2011; Love, 2003; Estok 2011; Nichols, 2011; Clark, 2015) that explain about human and environment. If it is viewed more deeply, ecocriticism is more about ecological aspect than psychological aspect. The ecocriticism seems to be in many areas of literary study.
Third, ecological psychology (Winter, 1996: 283) that discusses "as the study of human experience and behavior in, its physical, political, and spiritual context, in order to build sustainable world". Winter offers principle in relation to ecological psychology, as follows "(1) the goal of ecological psychology is to learn how to develop a sustainable culture; (2) the psychical world exists, whether we understand it or not; (3) our knowledge of reality is continually changing as our political, emotional, and intellectual knowledge changes; and (4) the connections between systems are more important than their separations (Winter, 1996: 296-298) “.

Fourth, environmental psychology that discusses about interaction between individual (human) and natural environment (Oliver, 2002, Gärling et al, 2002). It shows that environmental psychology focuses on environmental influences on human experience. In contrast, human influences on the environment, such as factors that affect behavior towards the environment and encourage humans to be proactive to the environment (Steg et al, 2013: 2). Canter (1986) calls environmental psychology is related to human experience with environment. Therefore, environmental psychology is close to sociology or social psychology. Environmental psychology seems very close to ecopsychology, but Reser insists that ecopsychology is not a variant of environmen- 
tal psychology. Ecopsychology is a "pseudo-science" study (Reser, 1996: 241).

All these disciplines, whether ecolinguistics, ecocritism, ecological psychology, ecopsychology, and environmental psychology have common focus, that is the study of human relation with environment. Therefore, it can be drawn a firm line about all discipline because they are still mutually 'borrow' terms. For example, ecolinguistics borrows the term from ecocritism or environmental psychology borrows the term from ecopsychology or vice versa. However, practitioners of each discipline must be able to provide their arguments that are related to their field.

\section{Research Focus}

Related to the study of ecopsychology development in Indonesia, the focus of this research is divided into two. First, the overview of ecopsychology studies in Indonesia. Second, the ecopsychology concretization of education in Indonesia today.

\section{REVIU OF RELATED LITERATURE}

\section{Ecopsychology}

Roszak, et. al. (1995) is considered as the first generation or the pioneer of ecopsyhology. This first generation of ecopsychology is spearheaded by T. Roszak, M. Gomes, A. Kanner, and R. Greenway. Ecopsychology in the first generation concentrates on the danger of disconnection between human and nature and how to restore human's concern about the nature and environment. Second generation of Ecopsychology emerges in the 2000s. At this time, there are ecopsychologists, e.g Fisher, Merrit, Vakoch, and Antonov. Ecopsychology at this time concentrates more on the segmentation of ecopsychology and therapeutic practice research (Fisher, 2013: 167; Davis, 2014: 51-52).

In the second generation of ecopsychology that is called the period of ecopsychology development, multicultural ecopsychology emerges. Anthony and Soule (1998: 161) asserts that multicultural ecopsychology is a diversity of ecopsychology in relation to social justice and environmental justice that creates harmony on earth. As a new discipline in psychology, ecopsychology is categorized as an interdisciplinary discipline (Doherty, 2009: 105; Norton, 2009: 138;) because it combines psychology and ecology in understanding the environment.

As there are many studies about ecopsychology, there are also journals about ecopsychology as follows. First, Ecopsychology (Mary Ann Liebert, Inc.) that emerges in 2009. Ecopsychology concentrates on articles about (1) physical and mental health benefits of interacting with nature; $(2)$ biophilia; (3) ecotherapy; (4) the psychology of environmental destruction; (5) science, technology, and the depth of experience with nature; (6) the rediscovery of the wild; (7) urban sustainability; (8) indigenous cultures; (9) responsibility for protecting natural places and other species; and (10) human-animal interaction. Second, the European Journal of Ecopsychology (EJE) appears in 2010. EJE concentrates on articles about (1) effects of the natural environment on our emotions and well-being; (2) how psychological disconnection relates to the current ecological crisis; and (3) furthering our understanding of psychological, emotional and spiritual relationships with nature.

An interesting thing in ecopsychology is the "pseudo-science" study (Reser, 1995: 241). Because of the "pseudo-science", ecopsychology study is more open, not (fully) objective, and "unboundaries". Thus, observers of nonpsychological disciplines (e.g literature, culture, or education) may use it for research purpose. In addition to ecopsychology journals, there are also websites and colleges that are related to ecopsychology.

\section{METHODOLOGY}

\section{Research Approach}

This research uses descriptive-qualitative approach. This approach is used to explain ecopsychology data in Indonesia descriptively. In line with Denzin \& Lincoln's (1997) view, in descriptive-quantitative research, the researcher uses data interpretation to find result.

\section{Instrument}

In this study, researchers act as a key instrument. Therefore, the researcher have to possess a high level of knowledge and interpretation. They are very necessary so that researcher is able to find good result and can be scientifically responsibilized.

\section{Data Analysis Technique}

In data analysis technique, the researcher performs three steps, namely (1) recording data about ecopsychology, (2) data classification, (3) data exposure, and (3) data verification. After that, the verification results are triangulated to maintain the reliability and validity levels.

\section{RESULT AND DISCCUSION}

\section{Ecopsychology in Indonesia}

In Indonesia, the study of ecopsychology has not been mainstream. Ecopsychology study in Indonesia are still "inferior" to the popularity of ecocritic study. There are two arguments about why ecopsychology in Indonesia is "less" popular than ecocritic.

First, the ecocritic is closer to the anthropology and sociology fields, whereas ecopsychology is closer to psychology. The area of anthropology and sociology studies are wider and more desirable than psychology. Therefore, literary studies (both writen and spoken literature) in Indonesia, there are many researchers who use the ecocritical approach. The ecocritical approach is usually associated with environmental ethics, ecofeminism, and environmental destruction.

Secondly, ecopsychology practitioner/expert in Indonesia still does not exist. Thus, ecopsychology study in Indonesia is still very rare because there is no practitioner. In addition, supporting literature about ecopsychology, e.g 
books, journals, or research in Indonesian language is still very rare. This is different from ecocritic, ecocritical books or studies in Indonesia have emerged, for example, Sudikan (2016) who writes a book of Ekologi Sastra.

Nevertheless, there are several writings on ecopsychology in Indonesia that appear in mass media, seminars, magazines, or research.

First, Ahmadi (2015) writes "Ecopsychology dalam Sastra Tiongkok" and it is presented in the National Seminar on Language, Literature, and Chinese Culture. It is discussed about the classical Chinese literature that is related to nature. A lot of classical Chinese literature 'pick' wisdom from nature. Therefore, human definitely cannot escape from nature.

Secondly, Ahmadi (2015b) writes Ecopsychology Literacy, Literature, and articles that discuss about the ecopsychology literature associated with Indonesian literature and environmental-themed movie. Ahmadi discusses about a novel by YB Mangunwijaya which explains a lot about human life with nature. In the movie context, Ahmadi shows environmental-themed movies, e.g Dr. Lorax, Wall E, Happy Feet which tell about interaction of human with the environment.

Thirdly, Ahmadi (2015c) writes an article of "Memahami Cerita Rakyat Indonesia melalui Kajian Ecopsychology". Ahmadi discusses the Indonesian folklores that have a tendency to relate to biophilia. Ahmadi points out that in Indonesian folklore is more likely to generate a positive value called biophilia (rather than a negative value[destruction]) called necrophilia in relation to nature, environment (plants and animals).

Fourth, Ahmadi (2016a) writes article "Literature Research in Indonesia, Ecopsychology Perspective". Ahmadi offers an alternative study in Indonesian literature using ecopsychology approach. He points out that ecopsychology is included in an interdisciplinary literary study because ecopsychology is an intersection between psychology and ecology. Ecopscyhology approach can be as main umbrella or as a 'scalpel' in analyzing literature.

Fifth, Ahmadi (2016b) writes articles on "Sastra, Ecopsychology, dan Alienasi Lingkungan." He discusses the linkage between literature and ecopsychology relating to human alienation to the environment. He points out that Indonesian literature also shows human alienation with the environment; its concretization is in the form of natural and environmental destructions, animal killings, and natural exploitation.

Sixth. Ahmadi (2016) writes a seminar article on "Ecopsychology, Green Literature, Nature". Ahmadi discusses ecopsychology that relates to the green literature in Indonesia. He points out that the study of green literature abroad is rife in the 90's. As in Indonesia, the study of new green literature is rife around the $2000 \mathrm{~s}$.

Seventh, Ahmadi (2017) writes a mass media article "Melawan Alienasi Lingkungan". This article is a small part of the ecopsyhology study. He points out that environmental issues are not as trendy as political issues. The community can look at how the community responds when the forest burns (burned on pupose or burns itself). The forests are explored completely. It seems like the people are not as panic as when the price of fuel rises or the racial issue emerging. In fact, the forest is the future of human. Without the forest, human beings will be powerless. Imagine, if in the future all forests are bare, oxygen supply is gone. It will certainly be the time of human extinction. Or, human only wish to be like in the kids movie, Dr. Deuss The Lorax (2012), tells Thneedville, a city full of plastic grass, plastic fish, plastic trees, and plastic flowers. In everyday life, they have to buy oxygen gallon. The question is, how much money should be spent to buy oxygen? Studies conducted by Jacoby (2001), White (2008), and Liddik (2011) show that the environment exploration and exploitation is increasing each year. Environment exploration and exploitation, according to Cianchi (2015) calls it "green criminology". Indonesia is also not free from the problem of environmental destruction. Hidayat (2016), Praja (2016), Fauzi, et al. (2010) identify that deforestation and forest burning in Indonesia are getting worse.

Ahmadi (2015-present) writes his dissertation on "Tipikal Manusia Biophilia dan Necrophilia dalam Novel Indonesia: Ecopsychology Perspective." He writes about the latest Indonesian novel in which it speaks of biophilian and necrophilian using ecopsychology as the main framework.

\section{Ecopsychology and its Concretization in Education in Indonesia}

In the Department of Language and Literature of Indonesia, Universitas Negeri Surabaya, there is Literary Psychology course. In the course, we provide material about ecopsychology. The subject of ecopsychology in Literature Psychology course is new and is raised in 2015. The details about ecopsychology material in Literature Psychology course cover four stages.

\section{The first stage: an early understanding of ecopsycholog}

Students discuss history material about the birth of ecopsychology. Previously, students are asked to prepare relevant materials to ecopsychology. To ease the student understanding, lecturers provide a draft on ecopsychology. As for ecopsychology explanation and exploration, students are asked to independently search for supporting literature (online or print).

\section{The second stage: an understanding of the flow/field o arable in ecopsychology}

Students discuss material about the fields in ecopsychology. The fields of ecopsychology, e.g the field of research, ecopsychology as classified by Davis (2014: 4) is related to (1) wilderness experiences, (2) ritual (3) indigenous people, (4) natural spirituality, and (5) an animistic view that the earth as e live as sentient. Doherty (2010: 203) classifies that research in ecopsychology is related to (1) emotion, (2) transcendence, (3) mystery, (4) status quo criticism, mysticism, helplessness and empowerment, and ecocentricity. Roszak (1995: 5) classifies ecopsychology research in (1) psychoecology, (2) global therapy, (3) ecotherapy, (4) green therapy, (5) earth centerered therapy, (6) re-earthing, (7) na- 
ture based psychotherapy, and (8) shamanic counseling. As for ecofeminism, according to Holloway et. al., (2014) is also included in ecopsychology research. The classification made by ecopsychologist cannot be separated from the view that ecopsychology as the main umbrella of the research. Thus, other relevant fields to ecopsychology are included in the research branch.

In therapeutic practice field, ecopsychology is used in the following context. Feral (1998 \& 1999) uses ecopsychology for children therapy; Rhodes (2008) uses ecopsychology in modern day human therapy through ecospiritual and ecofeminism; Wood (2010) uses ecopsychology with ecospiritual therapy; Burn (2012) \& Tudor (2013) use ecopsychology for ecotherapy that leads to self-therapy; Hafford (2014) uses ecopsychology for adventure therapy; And Black (2015) uses ecopsychology for natural therapy of healing.

\section{Third stage: understanding of literature in ecopsychology perspective}

In this section, students in groups are asked to discuss literature (foreign literature or Indonesian literature) in relation to ecopsychology. Lecturers provide modeling in literature forms, either novels, short stories, poems, or dramas in which are associated with ecopsychology elements.

Students are asked to find the ecopsychology element contained in the literary work. After that, they (in groups) are asked to present their discussion results or findings in front of the class. The other groups respond to their friend's presentation.

\section{The fourth stage: ecopsychology application in literary studies}

After understanding ecopsychology ontologically, axiologically, and epistemologically, students (individually) are asked to write literary criticism (over 2000-3000 words) using an ecopsychology perspective. The literatures sre novels, short stories, poetry, or drama. The students have 7 days to write articles about literature and ecopsychology. Later, the lecturers provide ecopsychology feedbacks from the students.

\section{Future plan: ecopsychology in Indonesia}

Ecopsychology is an interdisciplinary study. Therefore, the ecopsychology study is an alternative in answering contemporary issues that are getting more complex. In Indonesia, ecopsychology study can grow rapidly if it meets four principles, namely (1) researchers who strengthen ecopsychology study in research, book writing, journal writing and publishing, and formation of ecopsychology associations/ communities; (2) the government provides research assistance related to ecopsychology and provides knowledge on ecopsychology to the wider community through electronic or nonelectronic media; (3) for teachers/lecturers, they introduce ecopsychology in learning materials; and (4) the community learns, initiates, supports, and practices ecopsychology in everyday life.

\section{CONCLUSIONS}

Based on the exposure in advance, it can be summarized as follows. The development of ecopsychology in Indonesia has existed and characterized by research related to ecopsychology. Ecopsychology research in Indonesia is more likely to study about literature, movie, and media. The ecopsychology in psychology or ecology fields do not exist in Indonesia. And then, the ecopsychology concretization of education in Indonesia appears in the study of Literary Psychology.

\section{ACKNOWLEDGMENT}

1. Our thanks to Prof. Budi Darma, Ph.D. (author and literary critic) who has provided suggestions to sharpen this paper.

2. Our thanks to Prof. Dr. Setya Yuwana, M.A. (anthropologist and environmental litteraturer) who has provided suggestions about literary and environmental literature.

\section{REFERENCES}

Ahmadi, A. (2014). Ecopsychology dalam sastra tiongkok. Paper presented in National Seminar Mandarin Language, November $30^{\text {th }}$ at Unesa, Surabaya.

Ahmadi, A. (2015a). Literasi ecopsychology, sastra, dan film. Paper presented in National Seminar, October $23^{\text {th }}$ At Unesa, Surabaya.

Ahmadi, A. (2015b). Memahami cerita rakyat indonesia melalui kajian ecopsychology. Paper presented in National Seminar Bahasa, Sastra, dan Seni di Era Industri Kreatif, November 14th At UM, Malang.

Ahmadi, A. (2015c). Literature research in indonesia, ecopsychology perspective. Paper presented In International Conference On Educational Research and Development (ICERD), December $5^{\text {th }}$ At Unesa, Surabaya.

Ahmadi, A. (2015d). Psikologi sastra. Surabaya: Unesa Press. Ahmadi, A. (2016a). Ecopsychology, sastra, dan film. Radar Bojonegoro, 5.

Ahmadi, A. (2016b). Sastra, ecopsychology, dan alienasi lingkungan. Widyawara, 7, 42-44.

Ahmadi, A. (2017). Melawan alienasi lingkungan. Jawa Pos, 4.

Ahmadi, A. (2016c). Ecopsychology, green literature, nature. Dalam Wiyatmi, E. Liliani, \& D. Budiyanto (Peny.), Sastra Hijau dalam berbagai Media (127-133). Yogyakarta: HISKI \& Interlude.

Anthony, C. \& Soule, R. (1998). A multicultural approach to ecopsychology. The Humanistic Psychologist, 26 (1-3): 155-161.

Burn, C.A. (2012). Embodiment and embedment: integrating dance/movement therapy, body psychotherapy, and ecopsychology. Body, Movement, and Dance in Psychotherapy, 7, 39-54.

Black, M. (2015). The trees were our cathedral: a narrative inquiry into healing from addiction through a relationship with nature. Dissertation unpublished. California: California Institute of Integral Studies.

Canter, D. (1986). Environmental (social) psychology: 
an emerging synthesis. In D. Canter, J.R. Jesuino, L. Soczka, \& G.M. Stephenson (Eds.), Environmental social psychology (pp.1-18). Boston: Kluwer Academic Publishers.

Cianchi, J. (2015). Radical environmentalism nature: identity and more-than-human agency. New York: Palgrave.

Clark, T. (2011). Literature and the environment. Cambridge: Cambridge University Press.

Clark, T. (2015). Ecocriticism on the edge. London: Bloomsbury Publishing.

Davis, J. (2014). Diamond in the rough: an exploration of aliveness and transformation in wilderness. In D.A. Vacoch \& F. Castrillón (Eds.), Ecopsychology, phenomenology, and the environment: the experience of nature (pp. 47-63). New York: Springer.

Denzin, N.K. \& Lincoln, Y.S. (1997). Handbook of Qualitative Research.California: Sage Publication.

Doherty, T. J. (2009). The rediscovery of ecopsychology. Ecopsychology, 1, 105-109.

Estok, S.C. (2011). Ecocriticism and shakespeare: reading ecophobia. New York: Palgrave.

Fauzi, A., dkk. (2010). Status lingkungan hidup indonesia 2010. Jakarta: Kementerian Lingkungan Hidup.

Feral, C.H. (1998. The connectedness model and optimal development: is ecopsychology the answer to emotional well-being? The Humanistic Psychologist, 26, 243-274.

Feral. C.H. (1999). Connectedness and development: a theory is ecopsychology the answer to emotional well-being? Paper presented at the Annual Convention of the National Association of School Psychologists (New Orleans, LA, 28 April). (Online), (http://www files.eric. ed.gov).

Fisher, A. (2013). Radical ecopsychology: psychology in the service of life. New York: State University of New York.

Garrard, G. (2004). Ecocriticsm. London: Routledge.

Gärling, T., Biel, A., \& Gustafsson, M. (2002). The new environmental psychology: the human interdependence paradigm. In Robert B. Bechtel and Arza Churchman (Eds.). Handbook environmental psychology (pp. 85-94). New York: John Wiley \& Sons, Inc.

Glotfelty, C. \& Fromm, H. (1996). The ecocriticism reader: landmark in literary ecology. London: The University of Georgia Press.

Hafford, W. (2014). Wild minds: adventure therapy, ecopsychology, and the rewilding of humanity. Dissertation unpublished. New-England: Antioch University.

Hidayat, H. (2016). Forest resources management in indonesia (1968-2004): a political ecology approach. London: Springer.

Holloway, J.A., Murray, J., Okada, R., \& Emmons, A.L. (2014). Ecopsychology and relationship competency: the empowerment of women graduate students through nature experiences. Women \& Therapy, 37, 141-154.

Jacoby, K. (2001). Crimes against nature. Berkeley: University of California Press.

Liddik, D. R. (2011). Crimes against nature: illegal industries and the global environment. California: Praeger.

Nichols, A. (2011). Beyond romantic ecocriticism. New York: Palgrave.

Norton, C.L. (2009). Ecopsychology and social work: creating an interdisciplinary framework for redefining person-in-environment. Ecopsychology, 1 (3):138-145.

Roszak, T. (1995). Where psyche meets gaia. In T. Roszak, Gomes, M.E. \& Kanner (Eds.), Ecopsychology: Restoring the earth, healing the mind (pp. 1-9). San Fransisco: Sierra Club Books.

Roszak, T., Gomes, M.E. \& Kanner (Eds.). (1995). Ecopsychology: Restoring the earth, healing the mind. San Fransisco: Sierra Club Books.

Sapir, W. (1912). Language and environment. America Anthropologist, 2, 226-242.

Stibbe, A. (2015). Ecolinguistics: language, ecology and the stories we live by. Routledge: London \& New York.

Schultz, B. (2001). Language and the natural environment. In A. Fill \& P. Mühlhäusler (Eds.), The ecolinguistics reader: language, ecology and environment (pp. 109-114). London: Continuum.

Steg, L., van den Berg, A. \& de Groot, J. (Eds.). (2013). Environmental psychology. Oxford: Blackwell.

Tudor, K. (2013). Person-Centered psychology and therapy, ecopsychology and ecotherapy. Person-Centered \& Experiential Psychotherapies, 12, 315-329.

Love, G.A. (2003). Practical ecocriticism. London: University of Virginia Press.

Oliver, K. (2002). Psychology in practice.London: Hodden Anor.

Praja, A.P. (2016). Tantangan baru aphi. Kompas, hlm.7.

Reser, J.P. (1996). Whither environmental psychology? the transpersonal ecopsychology crossroads. Journal Environmental Psychology, 16, 235-267.

Rhodes, D. (2008). An anarchist psychotherapy: ecopsychology and a pedagogy of life. Dissertation unpublished. Greensboro: University of North Carolina.

White, R. (2008). Crimes against nature environmental criminology and ecological justice. Canada: Willan Publishing.

Winter, D.D. (1996). Ecological psychology: healing the split between planet and self. New Jersey: Lawrence Erlbaum Associates.

Wood, R. (2010). Psycho-Spiritual transformation experienced by participants of modern wilderness rites of passage quests: an intuitive inquiry. Dissertation unpublished. California: Institute of Transpersonal Psychology. 